\title{
A short report from the Editorial Office
}

Similar to last year, in this first issue of January 2012, we would like to summarize the recent progress made by the Chinese Science Bulletin (CSB), and to wish all of our editorial board members, reviewers, authors, readers, and collaborators a happy New Year.

First, we are very pleased to announce the progress made in 2011: in March 2011, the CSB won "The Chinese Government Award for Publishing", which is the highest award for China's science and technology journals and is a recognition of the journal's quality. Winning the award means that the CSB is considered one of the Top 10 Chinese science and technology journals last year. The Journal's JCR impact factor (IF) has increased to 1.087. Total citations have reached 6148, ranking 8th among the 57 journals in multidisciplinary sciences. The number of downloads from SpringerLink rose to 275102, and continues to increase. Additionally, the CSB began to publish Open Access manuscripts in 2011, and hopefully this will bring wider international recognition.

In 2011, 11 exciting special issues (topics) were published: Space Physics \& Space Weather, edited by Prof. LU QuanMing; Bioenergy, edited by Prof. JIN HongGuang; Conservation Biology of Endangered Wildlife, edited by Prof. FANG ShengGuo; Climate Change over the Past Millennium in China, edited by Prof. ZHOU XiuJi; DNA Damage, Signaling and Repair, edited by Prof. ZHOU PingKun; Bio-spectroscopic Sensing, edited by Prof. MA HuiMin; Endophenotype Strategies for the Study of Neuropsychiatric Disorders, co-edited by Profs. CHAN Raymond Chor-kiu, GOTTESMAN Irving I \& FU XiaoLan; For 100th Anniversary of the Birth of Professor Cheng-Hou Lou, edited by Prof. WU WeiHua; Statistical Physics and Mathematics for Complex Systems, edited by Prof. WANG Qiuping Alexandre; Geological Processes in Carbon Cycle, edited by Prof. YUAN DaoXian; and Bulk Metallic Glasses, edited by Prof. YAO KeFu. We sincerely thank the editors' considerable efforts in organizing these special issues (topics) and in improving the Journal's quality. We hope these contributions were appreciated by our readers.

Four prominent scientists were appointed Executive Associate-Editors-in-Chief and 31 new members (including 13 from abroad) joined the CSB Editorial Board in 2011, which makes the Editorial Board stronger and more international than ever before. In addition, three productive Editorial Board Meetings were held in 2011: in July, the meeting of the Editor-in-Chief and the Executive Associate Editors-in-Chief was held in Beijing, in October the Editorial Board Meeting on Petrology and Geochemistry was held in Xi' an, and in November, the Editorial Board Meeting of Life Sciences was held in Beijing. The Editorial Board meetings involved discussions regarding challenges the Journal is currently facing and the Journal's plans for future development. One of our goals for the near future is for the CSB to be included in Medline. We look forward to working with the Editorial Board towards this goal in the years ahead.

In accordance with the Journal's policy, the Editorial Board selected from all papers published during 2008-2009 two review articles [1,2] and three research articles [3-5] as the CSB's "Second Best Papers". We would like to congratulate the authors on their prize and thank them for their excellent contributions to the CSB.

Finally, we wish to express our sincere gratitude again to everyone in contributing to the development of the CSB in the past year. Through the support and efforts of the Editorial Board, we will continue to strive to make the CSB a leading international journal.

1 Zheng Y F. A perspective view on ultrahigh-pressure metamorphism and continental collision in the Dabie-Sulu orogenic belt. Chin Sci Bull, 2008, 53: 3081-3104

2 Wang P X. Global monsoon in a geological perspective. Chin Sci Bull, 2009, 54: 1113-1136

3 Xie L W, Zhang Y B, Zhang H H, et al. In situ simultaneous determination of trace elements, U-Pb and Lu-Hf isotopes in zircon and baddeleyite. Chin Sci Bull, 2008, 53: 1565-1573

4 Li Y M, Jiang G B, Wang Y W, et al. Concentrations, profiles and gas-particle partitioning of PCDD/Fs, PCBs and PBDEs in the ambient air of an E-waste dismantling area, southeast China. Chin Sci Bull, 2008, 53: 521-528

5 Xu F X, Chen W, Wang S, et al. Field experiment on a robust hierarchical metropolitan quantum cryptography network. Chin Sci Bull, 2009, 54: 2991-2997

AN Rui, Ph.D. Executive Director ZHANG Li, Ph.D. Deputy Director Editorial Office of Chinese Science Bulletin

Open Access This article is distributed under the terms of the Creative Commons Attribution License which permits any use, distribution, and reproduction in any medium, provided the original author(s) and source are credited. 